\title{
Sustainability governance and legitimisation processes: Gulf of Mexico oil spill
}

\author{
Nader Elsayed and Sameh Ammar \\ Department of Accounting and Information Systems, \\ College of Business and Economics, Qatar University, Doha, Qatar
}

Sustainability governance and legitimisation

processes

\begin{abstract}
Purpose - The purpose of this paper is to explore the emergence of sustainability governance through the unfolding hybridisation process between corporate governance and corporate social responsibility and the implications of this for understanding patterns in sustainability reporting over time.

Design/methodology/approach - The Gulf of Mexico oil spill incident is an extreme case study undertaken to examine its implications on the organisational legitimacy of British Petroleum (BP) and the latter's response to the incident and beyond. The paper draws on Suchman's legitimacy framework (1995) to understand sustainability governance as an organisational practice that evolved post the Gulf of Mexico oil spill to manage BP's legitimacy. It draws on archival records and documentation from 2008 to 2017, as key sources for data collection, using interrogation by NVivo software.

Findings - Sustainability governance is a sound practice that was socially constructed to manage the relegitimatisation process following the Gulf of Mexico oil spill. It is characterised by broadness (the interplay between the corporate governance and corporate social responsibility disciplines), dynamic (developing the tactics to repair and maintain legitimacy), agility (conforming to the accountability for socially responsible investment and ensuring steps towards geopolitically responsible investment) and interdependence (reflecting composition and interactions).

Practical implications - This paper has practical implications for organisations, in terms of sustainability governance's constitution, mechanism and characteristics.

Social implications - This paper has implications not only for organisations, in terms of sustainability governance's characteristics, but also for policy-makers, regulators and accounting education. However, the present paper's insights are achieved through an in-depth and longitudinal case study.

Originality/value - This paper has problematized the concept of sustainability governance and elaborated its evolution (the emergence, enactment, deployment and interplay) process. The sustainability governance showed an otherwise organisational response that moves our understanding of the deployment of disclosure for complex organisational change as a way to discredit events.
\end{abstract}

Keywords Sustainability, Legitimacy, Corporate governance, Archival analysis, Gulf of Mexico oil spill Paper type Research paper

\section{Introduction}

Prior research has increased our understanding of a number of requirements that relate to good corporate governance practice for diversified targets. One of these requirements is an

(C) Nader Elsayed and Sameh Ammar. Published by Emerald Publishing Limited. This article is published under the Creative Commons Attribution (CC BY 4.0) licence. Anyone may reproduce, distribute, translate and create derivative works of this article (for both commercial and noncommercial purposes), subject to full attribution to the original publication and authors. The full terms of this licence may be seen at http://creativecommons.org/licences/by/4.0/legalcode

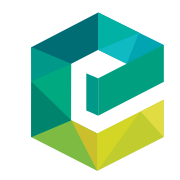


SAMPJ

11,1

enhancement of corporate disclosure and performance (Ho and Shun Wong, 2001). Another is the establishment of value-creating relationships with overall stakeholders (Boyd et al., 2011). There is additionally a need to provide the foundations for good corporate social responsibility (Haniffa and Cooke, 2005). Alternatively, there is other extant literature which has evidenced the vital role of sustainability in making it possible to respond to, and manipulate, institutional pressures (Wijethilake et al., 2017), facilitating the defender or prospector business strategy (Yuan et al., 2018), influencing, or being influenced by, organisational performance (Diouf and Boiral, 2017) and reporting to react or impress (Vourvachis et al., 2016). It has been highlighted on many occasions that the group of stakeholders puts enormous pressures on corporations to pursue high standards of social and environmental responsibility in terms of, for instance, reducing carbon emissions or complying with human rights, safety and environmental standards (Diouf and Boiral, 2017; Wijethilake et al., 2017). In consequence, corporations are facing a key challenge in sustaining the design and implementation of managerial practices to capture these growing pressures in the light of today's rapidly changing environment; otherwise,critical financial, environmental and reputational risks may arise. If successful, then these potentially negative effects can be avoided or minimised in the case of such occurrences, and the organizational managers will be afforded a degree of autonomy in making appropriate decisions about how and where business will be conducted.

There has been a call to investigate the bridging of the interactions between sustainability oversight and management (Stein and Wiedemann, 2016). Conceptually, this underlines sustainability governance that underscores the interdisciplinary of corporate governance and sustainability. Whilst prior studies have examined the organisational response to incidents through information disclosures (Noronha et al., 2015; Vourvachis and Woodward, 2015), the implications of such incidents for organisational change have not yet been given attention in the literature. A recent paper by El-Bassiouny and Letmathe (2018) empirically investigates the adoption of corporate social responsibility (CSR) practices and whether this adoption is triggered more by internal efficiency forces or by external legitimisation forces. However, they did not discuss how sustainability governance is constructed. By examining British Petroleum's (BP) responses in terms of information disclosures in relation to the Deepwater Horizon (DWH) incident, the current study responds to recent research calls (Stein and Wiedemann, 2016) and increases our understanding of the mechanisms that managers have adopted to identify, prioritize, manage and report on sustainability. In this study, we focus on the interactions between sustainability and corporate governance by considering who is governing sustainability's roles and how sustainability's implications are being monitored and managed.

In April 2010, the DWH incident caused a massive oil spill in the Gulf of Mexico, and it pushed BP to the forefront of the media and political attention worldwide, claimed the lives of 11 men and injured others, and a $\$ 20 \mathrm{bn}$ fund was initially set up to demonstrate BP's willingness and capacity to pay all legitimate claims for compensation. Likewise, many incidents had been investigated in previous literature. For instance, four catastrophic accidents that were suffered by major airlines in the years 2000, 2001 and 2009, which resulted in significant numbers of deaths and casualties (Vourvachis et al., 2016). Another example, provided by Noronha et al. (2015), relates to the deadly Wenzhou train accident in China, which caused a total of 40 people to be killed, and at least, 192 injured in July, 2011. Furthermore, the collapse of a garment factory in Bangladesh caused 1,134 deaths and over 1,650 injuries in 2013 (Wijethilake et al., 2017). Such incidents raise serious concerns and they threaten the continuation of corporations because of unsustainable management practices. Consequently, the progression of corporate governance in responding to such 
sustainability pressures has become substantial when addressing sustainability challenges and gaining social legitimacy. In this sense, the BP Chairman stated that:

$[\ldots][t]$ he spill that resulted caused widespread pollution. Our response has been unprecedented in scale, and we are determined to live up to our commitments in the Gulf. We will also do everything necessary to ensure BP is a company that can be trusted by shareholders and communities around the world" (BP plc, 2010, p. 6).

This caused the attention of the research to be drawn to seeking an understanding of the governance and legitimisation processes processes through which organisational legitimacy and the response of BP were managed, to address the implications of this incident.

This paper, therefore, examines BP's response to an environmental incident that has brought their organisational legitimacy into question. This investigation was focused on the Gulf of Mexico oil spill incident, for which BP was responsible. BP's organisational archive from 2008 to 2017 was the key source of data collection, and it was managed within, and rigorously interrogated through, NVivo. This process has revealed key insights into sustainability governance, as an organisational practice that has played a vital role in managing BP's response and legitimation process. It argues that broadness, dynamism, agility and interdependence are four characteristics that underline sustainability governance, which may have implications for teaching about, researching into and regulating corporate governance.

After this introduction, the remainder of this paper is organised as follows: the second section reviews the theoretical framework of legitimisation. The third section discusses the research design, which includes the research's approach and strategy, as well as the data collection sources and analysis. The sustainability governance case of BP is explored in the fourth section. The final section provides an overall review reflecting on what is possible to learn from the information contained in the case study.

\section{Theoretical framework}

Legitimacy theory is a widely defined perspective utilised to understand the role of organisations within economic, social and political contexts (Parker, 2005; Rezaee, 2016). This perspective is derived from the concept of organisational legitimacy that was initially defined by Dowling and Pfeffer (1975, p. 122), who stated that:

[. . . ] a condition or status which exists when an entity's value system is congruent with the value system of the larger social system of which the entity is a part. When a disparity, actual or potential, exists between the two value systems, there is a threat to the entity's legitimacy.

This indicates that any organisation both affects, and is impacted by, its broader social system, which reflects the society with which it interacts. Hence, it emphasises the implicit presence of a social contract between an organisation and its associated society, representing the expectations that society has about how an organisation should conduct its activities and operations in accordance with the values and norms of the society (Deegan et al., 2002; Rezaee, 2016). For instance, local communities' expectations were considered a crucial factor on the sustainability pathway that is shaped by building a trust between the examined case and the society in which it operates (Abdalla and A.K., 2015). In other words, the more societal expectations are accommodated by an organisation via strategy, the more trust there will be embedded within the relationship between an organisation and its related society. On the other hand, maintaining trust may result in organisational changes that pursue legitimisation. 
SAMPJ

11,1

Legitimacy dynamics are described in Suchman's definition of organisational legitimacy as, "a generalized perception or assumption that the actions of an entity are desirable, proper, or appropriate within some socially constructed system of norms, values, beliefs, and definitions" (Suchman, 1995, p. 574). This emphasises the dynamic motivations of organisations as a response to ensure that they operate within their societal expectations, in which the relevant publics continuously evaluate corporate output, mechanisms and objectives (Albertini, 2018). The ambition behind this is to legitimise corporate behaviours in the eyes of stakeholder groups and to voluntarily align their interests in terms of greenproduction, reputation and performance, with the long-term best interests of the society (Abdalla and A.K., 2015; Diouf and Boiral, 2017). This act of legitimisation triggers the organisation to adopt corporate governance mechanisms in running its operations, in favour not only of its shareholders but also of the society, to maintain the alignment between organisational actions and societal values (Suchman, 1995). Failing to reach such alignment may widen the legitimacy gap that underscores a lack of correspondence between the ways society believes an organisation should act and how it is perceived that the organisation has acted, upon which the society's trust may be questioned. In essence, seeking organisational legitimacy is considered significant in articulating that the organisation is in tune with societal concerns to provide support in closing any perceived legitimacy gaps (Dowling and Pfeffer, 1975).

The framework developed by Suchman (1995) extends legitimacy theory from Lindblom's (1993) framework. Suchman's framework articulates insightful lessons about organisational strategies of legitimacy (i.e. pragmatic, moral and cognitive), that are deployed to the relevant external audiences to address different purposes (i.e. gaining, maintaining and repairing), that are equipped by different tactics and all underline organisational dynamics towards legitimation. First, pragmatic legitimacy involves direct exchanges between an organisation and audiences that are represented by environmental regulators and institutional shareholders but may include broader political, economic or social connections (Suchman, 1995, p. 578). Second, moral legitimacy reflects positive normative evaluations of the organization and its activities relative to its social contract (Suchman, 1995, p. 579). It involves indirect interactions between audiences (represented by environmental general publics and small shareholders) and organizational actors, as the former remain a significant source of legitimacy because of their potential influence on organisational legitimisation (Mobus, 2005). The legitimacy dynamics of this strategy may predominantly rest on the evaluation of outputs and the consequences of organisational action (i.e. consequential legitimacy) or may rely on the evaluation of techniques and procedures (i.e. procedural legitimacy), in the absence of clearly observed consequences, with the purpose of achieving valued endings that are based on the organization's good-faith effort (Suchman, 1995). Third, cognitive legitimacy involves either confirmatory support for an organisation, or merely the recognition of the organisation based on necessity or on the unavoidable, which is subject to some taken-for-granted issues, suggesting therefore a third set of legitimacy dynamics which is based on cognition, rather than on interest or evaluation (Suchman, 1995).

Accordingly, the consideration of both organisational corporate governance progression and its associated information reporting, in relation to its social and environmental activities, is crucial in securing organisational legitimacy (Milne and Patten, 2002) and in enhancing sustainability in the eyes of the public (Vourvachis et al., 2016). Such social and environmental reports are deemed to be appropriate means that are mobilised to communicate with publics to gain, maintain or repair legitimacy and influence their perceptions and expectations (Cho and Patten, 2007; Mobus, 2005). This extends to 
strategies of impression management as ways of responding to environmental aspects (Diouf and Boiral, 2017; Guthrie and Parker, 1989) for the purpose of changing the perceptions of an organisation's relevant publics (Patten, 1992). Such associations are facilitated by the motives and choices of those involved in formulating strategy and taking decisions in the organisation (Maclagan, 1999). This is exemplified by the actions of corporate directors in relation to convincing a society that the organisation is socially responsible, and they are, thus, a part of the legitimisation process (Gray et al., 1995). Recently, Lueg and Radlach (2016) highlighted that setting up new organisational/ governance structures reinforces sustainability development and emphasises the need to overcome traditional behaviour through corporate management. This influence of corporate governance was further endorsed in the sense of CSR (El-Bassiouny and Letmathe, 2018; Majumder et al., 2017). Nevertheless, this conclusion advances our understanding through problematizing interrelations between corporate governance and sustainability. Developing a processual account articulates such interdisciplinary (the interplay of corporate governance with sustainability) in shaping sustainability governance over time in such a way that this seeking was given scant attention.

\section{Research design}

The research approach, its strategy and methods of data collection are designed in such a way as to advance our understanding of the evolution (emergence, enactment and interplay) process of sustainability governance and reporting. The three interrelated research design components are articulated in the subsequent sections.

\subsection{Research approach and strategy}

This paper draws on a qualitative approach so as to address the research question being dealt with in this paper, and it aims to elaborate the processes of the emergence, enactment, deployment and interplay of sustainability governance and reporting post the DWH incident. Whilst a qualitative approach enables the penetration of sustainability within the organisational control context in which they operate (Parker, 2012), it also enables the retrospective unpacking of the evolution of sustainability governance over time (Ahrens et al., 2008). This choice is supplemented by case study strategy to advance our understanding through drawing insights relating to day-to-day organisational life (Parker, 2012). Case study strategy is appropriate in answering "how" and "why" research questions, which require a detailed understanding of organisational processes. This is because of the richness of the data collected from its related contextual materials (Yin, 2009).

$\mathrm{BP}[1]$ was selected, focusing on the DWH incident as an illustrative and longitudinal case study (Scapens, 2004). The DWH incident is an extreme case study for a number of reasons. First, BP is multinational and it is one of the largest of the global companies, which specialises in oil and gas, holding investments in more than 70 countries[2]. This diversity could offer an opportunity to understand the complexity of organisational change in relation to an incident (Narayanan and Adams, 2016). Second, DWH is located in the Gulf of Mexico, where the incident happened, representing one of their most significant investments. Third, the DWH rig incident occurred in April 2010, and the ensuing massive oil spill in the Gulf of Mexico marked the largest oil spill in world history. It caused wide social and environmental implications, which have threatened BP's legitimacy because of BP being brought to the forefront of media and political attention in the UK, the USA and worldwide. For example, the US District Court ruled that BP had to pay civil penalties of up to $\$ 18 \mathrm{bn}[3]$, and a massive clean-up operation was run, at a total cost of around $\$ 28 \mathrm{bn}[4]$ by the end of 2014 . Understanding how such threats were overcome, and society relations managed, could offer 
SAMPJ

11,1

insights not only about disclosure but also about managerial responses (Mobus, 2005), as this incident put the trust between BP and its societal relations at stake. Fourth, this incident offered the opportunity to observe the attributes of the parties and actors who were involved in this organisational response (Michelon and Parbonetti, 2012; Shaukat et al., 2016), with the ambition of highlighting how BP's legitimacy is managed. Fifth, organisational response will be mainly examined during the period 2010-2017; however, the two years before the incident (2008 and 2009) are included to signal the changes in BP's response in the presence of a legitimacy threat (i.e. before and after the DWH incident), as well as in understanding the dynamics of the legitimisation process over time, including sustainability reporting (Mobus, 2005; Warsame et al., 2002).

\subsection{Data collection sources and analysis}

In this study, moral legitimacy is most relevant, because the BP Company shows a number of pieces of evidence to provide positive normative evaluations of the organization and its activities, relative to its interactions with society, with the objective of informing its organisational response to the DWH incident, which will be articulated in detail in Section 4. By drawing on moral legitimacy theory as the basis for our analysis, this paper draws on corporate reports to constitute "retrospective-sense making", that is, "a process of ex-post explanations or restatements or organizational outcomes and events" (Aerts, 2005). The reason behind this is to understand sustainability governance in relation to the DWH incident, as this crisis has raised questions regarding BP's legitimacy, environmental and social disclosures and its governance structuration. The incident data were collected from two main sources. First, the basic documents under examination in relation to the BP Company are the Annual Reports[5] for the period 2008-2017, especially important for its governance texture. Second, these are encompassed within the BP Company's data and records in its sustainability reports[6]. These pieces of documentation are available on the BP company website. An archival-based case study is adopted to extract sense and meaning from textual materials, so as to determine the presence of common concepts, themes, phrases and numbers in an objective manner (Yin, 2009). This archival-based case study[7] was conducted to review the nature of sustainability governance at BP, with a particular focus on the emergence and development of sustainability governance over the years under examination, and to explore the roles of the Gulf of Mexico and Geopolitical Committees in effectively shaping sustainability governances mechanisms to deal with the DWH incident.

Descriptive analysis was conducted by grouping and comparing several sources of data and information over the period under examination, by utilising NVivo. This is a qualitative analysis software, which is utilised with the ambition of gathering codes (i.e. references), identifying themes (i.e. nodes) and developing a story (i.e. mapping). The advantage of this process is that it enabled the researchers to retrieve data over time (BP Annual and Sustainability Reports) and the content of nodes (references) to check their relevance (Hutchison et al., 2010; Kikooma, 2004). These techniques assisted the research process through understanding the evolution (emergence, enactment and interplay) process of sustainability governance and reporting following the Gulf of Mexico oil spill.

\section{Case study: British Petroleum}

The evolution process of BP sustainability governance after DWH is unfolded in such a way as to theoretically inform this section. This narrative will be informed by the legitimacy theory framework developed in Section 2, aiming to understand how sustainability governance (a) emerged, (b) was enacted, (c) was deployed and (d) interacted with 
sustainability reporting, in responding to the DWH incident, and all these sub-processes are elaborated in the subsequent sections.

\subsection{Sustainability governance emergence}

DWH's implications and the conditions of emerging sustainability governance are unfolded here to go behind such change. This background is built around understanding society's perceptions of $\mathrm{BP}$ after DWH and the organisational response to such perceptions.

4.1.1 Reputation disturbance. Societies' perceptions of DWH provide a contextual account through which to illuminate our understanding of BP's response as a dynamic process. Such perceptions, as understood by the key players at BP, have shaped concerns not only towards society but also over BP's associations, which might be affected by ongoing implications, as stated: (BP plc, 2010, p. 27):

[... . the Gulf of Mexico oil spill has damaged BP's reputation, which may have a long-term impact on the group's ability to access new opportunities, both in the US and elsewhere. Adverse public, political and industry sentiment towards BP, and towards oil and gas drilling activities generally, could damage or impair our existing commercial relationships with counterparties, partners and host governments and could impair our access to new investment opportunities, exploration properties, operatorships or other essential commercial arrangements with potential partners and host governments, particularly in the US.

Arguably, the ongoing implications of DWH may not only affect BP's legitimacy but also threaten its existence both in the Gulf of Mexico region and in the industry (Patten, 1992; Suchman, 1995). Organisational reputation and trust became key issues that put BP's societal relations at stake and overtook BP's board meetings (BP plc, 2010, p. 91):

During the crisis and afterwards, the board had extensive discussions about the reputational impact of the event, including how it might affect BP's licence to operate both in the US and elsewhere. This work continues to focus on BP's relationship with shareholders, governments, communities and indeed all those who come into contact with $\mathrm{BP}$ through its business operations. The chairman, the chief executive, the chairman of SEEAC and senior management have been actively involved in discussions with shareholders and other groups in an endeavour to address concerns and to start to rebuild trust.

However, rebuilding organisational trust in such a way as to repair moral legitimacy requires substantial effort (Suchman, 1995). This is beyond the capability of the board or of the executive management. Alternatively, corporate governance was involved through having intensive meetings with executive management to shape the organisational response, as stated:

Over the year, the board met 25 times as we responded both to events in the Gulf of Mexico and subsequently in the financial markets, meeting at least weekly as the crisis developed. The board had to organize its work to respond to the crisis while ensuring the other parts of the company continued to perform (BP plc, 2010, p. 90).

This reinforces the research report, giving importance to internal corporate governance mechanisms as a key internal driver of sustainability to deal with threats to legitimacy and business continuation (El-Bassiouny and Letmathe, 2018; Passetti et al., 2014). In responding to the crisis and to maintain BP's survival, it provoked key actors at BP to engage in revolutionary change in their way of thinking and acting, as outlined by Carl-Henric Svanberg:

We were faced with a crisis in 2010 that could have threatened the very being of the company. A crisis that should never have happened. It required resolute action on many fronts to see us 
SAMPJ

11,1

260

through and it is a great tribute to everyone in BP that the foundations were laid for our recovery. This involved doing things differently and thinking differently. We had to act simultaneously on many fronts (BP Chairman, BP plc, 2010).

This way of rethinking brought BP's organisational values into question and the three new organisational values were developed to reflect the incident and stakeholders' perception of BP following DWH's acknowledgment, as declared by the BP Chairman:

Clearly, after a very troubled and demanding 12 months, BP is a changed company. As a board, we have much to do, and we are working with the executive team to ensure successful implementation of a refocused strategy built on the pillars of safety, trust and value creation (BP plc, 2010, p. 7). He added that: Safety must be enhanced and embedded. Trust must be regained. Value must be created through a clear strategic plan. While these priorities are simple to express, substantial activity is required to turn them into tangible and lasting change (BP plc, 2011, p. 8).

Safety, trust and value were introduced as core values and should drive organisational resilience in terms of regaining legitimacy and business continuation. Altered values relevant to publics conform to societal expectations, and presenting $\mathrm{BP}$ in a positive sense involves managerial responses to legitimacy threats (O'Donovan, 2002). These changes reflect a moral legitimacy strategy deploying a repair tactic by the use of which organisational behaviour could be changed (Mobus, 2005; O'Donovan, 2002). That is, BP refocusing its strategy-centred altered values was a selective frame put in place to respond to an environmental litigation "discrediting" event (Warsame et al., 2002).

The process of self-reflection, values re-identification and strategy development underscores the dynamics of $\mathrm{BP}$ in responding to DWH. All of the processes are dedicated to regaining trust and to keeping $\mathrm{BP}$ surviving alike. In this sense, the operationalisation process of new core values throughout BP involved further organisational changes. Whilst these changes were facilitated by $\mathrm{BP}$ corporate governance, the latter was not isolated from these changes, as reported by the BP Chairman Committee:

During 2011, the board undertook a review of its corporate governance model.[...] The review concluded that BP's system of governance is robust but that further clarity on board processes would help reinforce the board's delegation to the group chief executive and strengthen the board's monitoring and assurance role (BP plc, 2011, p. 120).

More specifically, BP corporate governance has undergone a re-structuration process that was driven by a refocused strategy that was developed and put in place to address legitimatisation and continuation. This expands on recent research which shows that altered organisational values became core to informal control in shaping formal controls, that is, sustainability strategy and corporate governance, in promoting shared environmental values and beliefs throughout BP (Heggen, 2018; Jollands et al., 2015; Riccaboni and Leone, 2010). It cascades down from the refocused strategy to the directorships' process, as reported (BP plc, 2011, p. 120):

The composition of the board and the mix of knowledge, skills and experience that our directors bring to the company is a key area of focus for the nomination committee. The committee keeps this mix under review and regularly maps the skillset of our existing board membership against the likely tenure of individual directors. This is viewed against the potential demands placed on the board due to developments in our strategy and business activities.

This restructuration has resulted in the emergence of two new committees that are designated to address the implications of DWH. Legitimisation and continuation became two dimensions of BP sustainability that needed to be monitored and governed at board level, because of the critical nature of the incident. The enactment and deployment processes 
by which designated committees on sustainability governance deal with both dimensions are unfolded in subsequent sections.

4.1.2 Trust restoration. Following the DWH incident, there was a realisation that BP's reputation was at stake, not only in the Gulf of Mexico but also in all of the societies in which $\mathrm{BP}$ is operating. This perception was shaped by interaction between external and internal forces that resulted in establishing the Gulf Coast Restoration Organization (GCRO) in June 2010 (Abdalla and A.K., 2015; Zhao and Patten, 2016). Externally, BP faced significant pressures from the US President, Barak Obama, who called the BP Chairman, Carl-Henric Svanberg, to a meeting. In this meeting, they discussed BP's responsibility for the effects of the DWH oil spill, one that could not be stopped until 16 June 2010. The oil spill caused litigation in multiple districts, as well as cases started by non-governmental organisations that are concerned with the environment and wildlife in the Gulf of Mexico, thus calling for urgent action. This pressure was materialised through action at board level and through establishing GCRO, and this was the cornerstone to discrediting the DWH incident (Warsame et al., 2002). The GCRO is an executive unit that deals directly with the incident's implications to discharge BP's responsibility, as outlined in the Annual Report (BP plc, 2010, p. 104):

The Gulf Coast Restoration Organization was set up to manage the company's response activities. This organization has created the framework designed to enable the company to manage the operations and transactions now arising from the incident; including clean-up and restoration costs, claims management and litigation.

So, the GCRO was designed to assure the accountability of BP for the implications of DWH through two key tasks, namely, restoration and litigation (Dowling and Pfeffer, 1975). Consequently, the GCRO was to provide the necessary leadership and dedicated resources to facilitate BP's fulfilment of its clean-up responsibilities and to support the long-term effort to restore the Gulf Coast (BP plc, 2010, p. 32). Bob Dudley led the GCRO during June-October 2010, before becoming Group Chief Executive (GCE) of BP. At the beginning, the GCRO Director directly reported to the GCE on GCRO's progress, in terms of restoration and litigation. However, the restoration activities were completed in all of the states in 2013, with the exception of Louisiana. This response advances the knowledge demonstrated by prior studies about how impression management strategies were executed (Diouf and Boiral, 2017). More specifically, concerns over BP's trust and reputation are artefacts of stakeholders' perceptions and their indirect involvement in setting up strategic priorities (Kaur and Lodhia, 2018). Because of this burden and its criticality for BP's reputation, the GCRO itself has been subjected to further accountability and higher governance, through being overseen by a specific committee, as elaborated in the subsequent section.

\subsection{Sustainability governance mechanisms}

Processes of sustainability governance enactment and deployment are articulated here. They are processes that underline two roles for the organisational response to DWH, namely, conformance that focuses on legitimation and that is gained through defender processes and performance that concerns continuation, which is operationalised through prospector processes, as will be articulated in the subsequent sections.

4.2.1 Legitimacy governance. BP's legitimacy was at stake because of the major DWH incident in the Gulf of Mexico. Understanding the organisational response to this incident to regain legitimacy is retrospectively constructed and theoretically presented here. Having established GCRO, the BP Board subsequently formed the Gulf of Mexico (GoM) Committee 
SAMPJ

11,1

\section{2}

in 2010. The committee oversaw implications that arose from DWH, as stated by the BP Chairman:

A dedicated Gulf of Mexico committee was formed to enable the board to respond quickly and appropriately as events unfolded. During the summer, the chairs of the committees and I met regularly to ensure work was co-ordinated and the right issues were being addressed in a timely way (BP plc, 2010, p. 90).

The initiative of forming the GoM Committee is an operationalisation of a strategy of moral legitimacy (Suchman, 1995). It stemmed from:

- a recognition of a long-term scale response;

- overseeing GCRO's activities; and

- freeing up more of the Board's time to devote sufficient attention to overseeing the strategic direction of the group as a whole.

The key purpose of the initiative was:

[... . to provide non-executive oversight of the GCRO; to oversee the management and mitigation of legal and license-to-operate risks arising out of the Deepwater Horizon accident and the subsequent response; and to support efforts to rebuild trust in BP and BP's reputation, with a particular focus on the US [...] (BP plc, 2010, p. 101).

Analysing the GoM Committee's structure, purpose and operationalisation processes advances our understanding of the ways in which sustainability governance evolved over time (See Figure A1 in the Appendix). The committee was established during 2010, with six directors alongside the GCE, Bob Dudley, and it was terminated, with five members, in 2015. In the meantime, the committee was chaired by Ian Davis throughout, offering BP board experience in global, financial and strategic matters. This emergence advances the conclusion of Michelon and Parbonetti (2012) by articulating how there is an interrelationship between the competencies of board composition and sustainability orientation. In extending our understanding, the emergence of sustainability governance unfolds a deployment process that enabled BP to have a more comprehensive strategy that facilitates its proactive role (Shaukat et al., 2016).

More importantly, the GoM Committee was integrated with other BP committees, as stated by the committee's chair, Ian Davis: [t]he GoM committee has cross-membership with both the SEEAC and the audit committee, helping to inform discussions of matters within the committee's remit (BP plc, 2011, p. 130). For instance, Alan Boeckmann was a member of both the GoM and SEEA Committees during 2014-2015. In addition, the Chair of the GoM Committee, Ian Davis, was also a member of the Audit Committee. Similarly, Lain Conn and Dr Byron Grote have cross-memberships in the GoM, SEEA and Audit Committees. Paul Anderson is another representative of such interrelationships and was a committee member of SEEA and GoM during 2010-2017. Similarly, the GoM Committee is also accountable to the BP board, as reported here (BP plc, 2011, p. 130):

The committee chairman provides verbal reports at board meetings, and all directors are invited, from time to time, to attend and observe committee meetings. Meeting Minutes are sent to the board for review, and the board retains ultimate accountability for oversight of the group's response to the Deepwater Horizon accident.

These interrelations underline the lateral interdependencies that reinforce the integrity of legitimacy governance. This structuration lends support to van der Meer-Kooistra and Scapens' (2008) argument that minimal structures, which consist of four dimensions, 
namely, economics, the institutional, the social and the technical, are important in regulating lateral relations, but they should be flexible to enable reactions to new situations as they arise. The committee was monitoring these situations through society's perceptions, as reported by the US media, so as to rebuild trust and maintain BP's reputation, as reported:

[...] the political landscape and the views of the American people, in part from independent polling data relating to many aspects of BP's response to the incident. This has helped inform many of the committee's discussions, and the committee will continue to receive polling data on a regular basis in 2011 (BP plc, 2010, p. 102).

Sustainability governance and legitimisation processes

During the crisis, the committee was overwhelmed with activities, as follows (BP plc, 2010, p. 101):

- monitoring the remediation work to mitigate the effects of the oil spill in the waters of the Gulf of Mexico and on the affected shorelines;

- overseeing a co-ordinated response programme with affected communities and states and overseeing the approach for relationships with communities, states and the US Government on issues relating to the incident;

- overseeing BP's activities and responsibilities with respect to the Gulf Coast Claims Facility and the DWH Oil Spill Trust;

- overseeing expenditures and investments that fall outside the established claims administration process or any redirection of resources outside the normal course of business;

- overseeing the legal and communication strategy for litigation involving the company, or its subsidiaries, arising from the incident or its aftermath, including government claims for fines and penalties;

- overseeing the process for the distribution of the goodwill fund for rig workers who have been impacted by the drilling moratorium imposed by the US Government;

- overseeing the strategy connected with claims, recognizing the independent nature of the connected Gulf Coast Claims Facility; and

- reviewing and monitoring management strategy and actions to restore the group's reputation in the USA and supporting management in any activities aimed at that goal.

The aforementioned duties show the complementarity between the GoM Committee and GCRO. Whilst the latter was executing BP's response to the incident to regain trust, the former's role was to oversee this executive role to regain organisational legitimacy. The connection was obvious, in the words of the GoM Committee's Chair:

We have been joined in meetings by the leadership, management and counsel of the GCRO, which was formed in mid-2010 to manage the company's long-term response to the tragic Deepwater Horizon oil spill. The committee members' understanding of the important issues and numerous interdependencies has been facilitated by the frequency of meetings and the breadth of topics covered (BP plc, 2011, p. 130).

Since its formation, the GoM Committee had held an increasing number of meetings 9, 16, 23, 13 and 5, respectively, in 2010, 2011, 2013, 2014 and 2015. Externally, it was reviewing plans and progress in moving Gulf Coast shoreline response activities on. Internally, the committee was a mediator between GCRO and BP board oversight, thus giving $\mathrm{BP}$ conformance with implications arising from the DWH accident. These activities uncovered a 
SAMPJ

11,1

need to develop new metrics with which to measure, monitor and plan remediation activities, and metrics' development will be discussed in Section 4.3.

Legitimacy governance is an initiative that uncovers the dynamics of BP's organisational response to crisis so as to regain legitimacy, as the first dimension of sustainability governance. The BP board followed a strategy of moral legitimacy, mobilising both consequential and procedural tactics towards regaining trust (Suchman, 1995). Whilst the media were a source for evaluating the consequences, forming the GoM Committee was a procedural tactic that was dedicated to being sound organisational practice that developed to demonstrate that BP was making a good-faith effort to achieve trust (Mobus, 2005; Suchman, 1995). This was a long process that was governed by the emergence of the GoM Committee after it underwent corporate governance into the re-structuration processes. Having the GoM Committee, consisting of a spectrum of skilful members who were specialised in global and strategic affairs, enabled BP to form a comprehensive environmental strategy (Shaukat et al., 2016). This hybridisation between governance and sustainability is, in turn, governed by lateral relations (van der Meer-Kooistra and Scapens, 2008). This provides minimal interdependencies across the BP board and the executive management, where the value of each's works depends on that of the others (Grabner and Moers, 2013). In a nutshell, these organisational practices of sustainability governance played a defensive role in handling DWH's implications but the legacy experiences of which lead to a dedicated prospective role, as will be discussed in the consequent section.

4.2.2 Geopolitical governance. The implications and threats of DWH to the legitimacy of BP were overcome during 2010-2015. This left a legacy of accumulated experiences that have broadened the scope of sustainability governance. BP's attention was turning to endorsing its market position through sustainable development. The latter was, however, confronted by geopolitical risks, especially in a company that has multinational operations that must give attention to political intimidation. Deploying BP sustainability governance in enabling a prospective role is theoretically articulated here. Following the incident, the BP board's focus went beyond technical concerns that gave attention to the potential implications of geopolitics on BP investments worldwide. As outlined in Section 3.1, the BP investment map is geographically distributed over 70 countries, as reported:

The diverse locations of our operations around the world expose us to a wide range of political developments and consequent changes to the economic and operating environment. Geopolitical risk is inherent to many regions in which we operate, and heightened political or social tensions or changes in key relationships could adversely affect the group (BP plc, 2015, p. 52, 2016, p. 48, 2017, p. 56).

This investment map, alongside the DWH incident, was the key motivations for forming the Geopolitical (Geo) Committee in 2015. This formation is the materialisation of a strategy of general legitimacy that aims to police organisational accomplishment through monitoring BP's identification and its management of geopolitical risk (Suchman, 1995). Again, the Geo Committee repeatedly highlighted the importance of BP's reputation and trust in the society in which it is operating:

[BP] seek to actively manage this [geopolitical] risk through the development and maintenance of relationships with governments and stakeholders and becoming trusted partners in each country and region. In addition, we closely monitor events and implement risk mitigation plans where appropriate (BP plc, 2015, p. 52, 2016, p. 48).

Principally, the Geo Committee was assigned the following responsibilities from 2015 to 2017: 
(1) to monitor the company's identification and management of major and correlated geopolitical risk and to consider reputational as well as financial consequences:

(2) Major geopolitical risks are those brought about by social, economic or political events that occur in countries where BP has material investments that can be jeopardized.

Sustainability governance and legitimisation processes

(3) Correlated geopolitical risks are those brought about by social, economic or political events that occur in countries where BP may or may not have a presence, but that that may lead to global political instability.

(4) to review the company's activities in the context of political and economic developments on a regional basis and to advise the board on these elements in its consideration of BP's strategy and the annual plan.

As shown in Figure A1 in the appendix, the Geo Committee was established in 2015 with three directors, and it was chaired by Antony Burgmans. His experience in consumer facing business assisted the BP board in regard to how to maintain reputation, brand, culture and values. During 2016, the Geo Committee memberships were upgraded to four directors, after the appointment of Ian Davis, whereas Sir John Sawers took over from Antony Burgmans because of the latter's retirement. The Committee is laterally integrated with others through cross-memberships, so as to avoid overlap and/or omitted tasks. For instance, Sir John Sawers was a member of the SEEA Committee, and he has chaired the Geo Committee since 2016. In 2015, Antony Burgmans played the same role for the SEEA and the Geo Committees. More specifically, tasks undertaken by the Geo Committee have implications for both of the other BP board committees, and for strategy, as outlined in the 2017 Annual Report:

- identification and allocation of risks to the board and monitoring committees (the audit, SEEA and geopolitical committees) for 2017 and confirmation of the schedule for oversight; and

- geopolitics helps to consider how to further optimize the output of the work undertaken by the board, geopolitical committee and the international advisory board.

This type of constitution elaborates on existing research evidence that links the competencies of board composition and sustainability orientation (Michelon and Parbonetti, 2012) and the impactions of which enable them to be proactive and to have a comprehensive strategy (Shaukat et al., 2016). Whilst institutional interdependencies across the Geo, Audit and SEEA Committees, in relation to sustainable business development, exercise lateral governance (van der Meer-Kooistra and Scapens, 2008), this enables the Geo Committee to undertake proactive roles through inspecting BP's intended investment for business development, as has been documented:

The world continues to be a troubled place and the risks faced by BP are ever evolving. The board keeps under review its approach to the monitoring of risk - as demonstrated by the board's oversight of cybersecurity and the sharpened focus on geopolitical risk through the formation of the geopolitical committee (See BP Annual Reports 2015-2017).

In expanding the existing conclusion, the value creation of the Geo Committee is discussed along two paths of sustainable business development, namely, strategy and capital decisionmaking (Elmassri et al., 2015; Shaukat et al., 2016). First, members of the Geo Committee had inherited valuable experience from dealing with DWH. Utilising these competencies in 
participating indirectly in BP's strategy formulation through the BP board elaborates on Shaukat et al.'s (2016) conclusion. Whilst the BP Chairman and GCE attend and brief Geo Committee meetings, the BP board is acting upon the recommendations of the Geo Committee's Chair, Sir John Sawers, regarding geopolitical trouble. Similarly, second, the indirect involvement of the Geo Committee in BP's capital decision-making process, through the GCE, also advances existing understanding (Passetti et al., 2014). Whilst the GCE briefs Geo Committee meetings through his attendance, GCE acts upon the Geo Committee's recommendations. This integration was followed by a recommendation that the committee and the board felt that there should be greater integration between the work of the board and that of the committee (BP plc, 2017). All considered, in relation to issues that may affect all of BP's key geographies, Sir John Sawers stated that:

The evaluation concluded that the committee was working well and considering the right issues, but stressed the importance of considering the geopolitics in a country before an investment is made. The committee currently meets three times a year and is considering additional meetings (BP plc, 2017, p. 90).

This shows that members of the Geo Committee are indirectly involved in strategic investment decisions, as the Committee's Chair stated:

[The Committee] discussed BP's involvement in the key countries where it has investment or is considering investment in detail. These included Angola, the US, Russia, Mexico, Brazil, India, Mauritania and Senegal. It considered broader policy issues such as the US domestic and foreign policy under the new administration, and the political and economic impact of a low price on producing countries. We reviewed the geopolitical background to BP's global investments and the politics around climate change (BP plc, 2017, p. 90).

This pre-capital decision control advances the existing conclusion that non-financial considerations and objectives take precedence over technical accounting measures, such as the present value, especially in the aforementioned contexts, where political instability is being experienced (Elmassri et al., 2015, p. 151; Huikku et al., 2018). In reinforcing Alkaraan's (2016) findings, the Geo Committee screens and scans the potential implications of political and correlated issues, as documented in the committee's agenda from 2015-2017, as follows:

- In 2015, the issues discussed during the year included emerging geopolitical issues that could impact BP's business, developments in the Middle East and Latin America, the effects of migration in Europe and the 2016 US election (BP plc, 2015, p. 66).

- In 2016, the implications of the UK referendum on Brexit and the US presidential election were discussed at each meeting (BP plc, 2016, p. 78); and the impact of geopolitical events on BP's interests in the Middle East and in Egypt, Russia and Turkey.

- In 2017, the key issues included the global economy, developments in the Middle East, political events in Latin America and the political and economic outlook in the USA, as well as the UK's potential exit from the European Union (BP plc, 2017, p. 76).

The aforementioned agenda shows not only that BP has political connections that have a high-profile political background but also their involvement in BP's strategy and influence over strategic decisions relating to investment. This advances Elmassri et al.'s (2015) conclusion, by underscoring the role of political connections in strategic investment decision-making under extreme uncertainty. More importantly, these interdependencies 
between strategy formulation and geopolitical connections were moderated by the Chair of the Geo Committee, Sir John Sawers. To put it differently, sustainability governance not only is limited to the trust of society but also extends to include strategic risks around corporate investment, such as geopolitical troubles, about which executives may have an insufficient understanding. This indicates that BP has experienced an organisational transformation, moving from defender to prospector roles. The defender's role of legitimacy is represented by the GoM Committee, which emerged following the DWH incident, whereas the need for governance to identify and prioritise issues pertaining to sustainable development is a prospector's role, as represented by the Geo Committee. We argue that the prospector roles have been undertaken to go beyond legitimacy and to secure the continuity of $\mathrm{BP}$ in the region.

The emergence, deployment and operationalisation process of the GoM and Geo Committees are organisational practices that existed to enhance sustainability governance (Narayanan and Adams, 2016). This uncovers broadness as another characteristic of sustainability governance. It is the hybridisation of governance and sustainability that temporally existed through complex processes that enabled these defender and proactive roles. The focus of these roles moves from socially responsible investment to focus on geopolitically responsible investment. In a nutshell, sustainability governance played a vital role in enabling BP to act proactively, by the use of which sustainability reporting is not isolated, as will be discussed in the consequent section.

\subsection{Sustainability governance reporting}

The patterns of sustainability reporting published by BP over a period of 10 years are articulated in line with changes in sustainability governance and strategic priorities. In doing this, this section unfolds the strategizing process through which sustainability governance and strategy interact with the process of reporting sustainability (structure, metrics and indicators), which was not isolated, as shown in Figure A2 in the Appendix. This indicates the trends in the sustainability dimensions of BP throughout the period, 20082017, demonstrating the number of indicators that are included in each dimension. In 2008, BP put a focus on only three dimensions (safety, people and performance), without a clear focus on having a dimension under the title: Environment; however, we found that a number of environmental indicators are categorised under the safety dimension. From 2009 to 2015, an environmental dimension was categorized during the period in which the DWH incident in the Gulf of Mexico was being dealt with, indicating the restructuration of sustainability dimensions. In 2016, two dimensions were newly constructed, under the titles: "Greenhouse Gas Emissions" and "Value to Society", with the emergence of the Geopolitical Committee and the non-existence of the GoM Committee after the crisis had passed. In addition, the dimension "Performance" no longer existed in 2016, as the new vision of BP is to direct all indicators to enhance what they have called the "Sustainability Performance" of the overall company (BP plc, 2016).

In terms of the total number of indicators, this seems to have been stable (around 40 indicators) during the period of study, except during the past couple of years, with the emergence of two new dimensions, when the number of such dimensions increased to 47 in 2016 and 58 in 2017. This change highlights the increasing level of disclosure and transparency in sustainability reporting, and it reinforces the existing understanding that such changes reflect the stakeholders' perceptions (Diouf and Boiral, 2017; and Kaur and Lodhia, 2018). In terms of the number of indicators, on average, the Safety and Greenhouse dimensions constitute a large number of indicators (14 indicators each), followed by Environment and People (10 indicators each), Performance (8 indicators) and, finally, Value 
SAMPJ

11,1

\section{8}

to Society (4 indicators), as shown in detail in Figure A3 in the Appendix. This table indicates the trends shown by the sustainability performance indicators at BP throughout the period 2008-2017, demonstrating the dimensions' codes. These indicators, which total 72, have been prepared to reflect the most important sustainability issues for BP, as highlighted in the BP Sustainability Report 2017. It was noticed that the majority of indicators were newly created, reclassified (restructured) or dropped after the DWH incident.

For the newly created indicators during the period, we found that the DWH issue had a great influence on BP social disclosures, causing them to become more transparent to rebuild trust between the company and society, as consistent with Deegan et al. (2002). Such safety indicators created were, for example, "Losses of Primary Containment" and "Oil Spills in Land and Water", in 2010; in addition to "Safety events in Tier 1 and 2 processes", in 2012 and 2013, respectively. For Environment and Greenhouse dimensions, a number of indicators was introduced relating to Water, Oil and Gas Components, such as Carbon, Nitrogen, Methane, etc., which reflects the nature of BP's activities in 2016 and 2017. For the People and Culture dimension, the indicators of women at management level, and employee turnover, were created in 2010 to reflect concerns relating to gender diversity on the board and the number of employees who had left BP and had been replaced by others directly after the crisis. This was done to show, in some way and somehow, that BP was putting a focus on hiring more talented and skilled personnel.

For the reclassified indicators during the period, the significant change to sustainability performance indicators was done here, which, again, is a change in BP's sustainability governance's scope. This reclassification in sustainability indicators can be deemed to be a legitimacy mechanism that BP utilises to dialogue with stakeholders (Michelon and Parbonetti, 2012). A number of indicators have been restructured from Safety to the Environment, or vice versa, such as oil spills to land and water, the volume of oil spilled and the volume of oil unrecovered, environmental and safety fines, environmental expenditures, etc. Another group of indicators were restructured from the Environment to Greenhouse in 2016, whilst, in 2017, the Greenhouse indicators were reclassified under Operation Controls or Equity, to differentiate between the activities that are operated 100 per cent by BP and others that are shared with counterparts. We found also a couple of indicators that were restructured from Performance to People in 2008 (i.e. Remuneration Packages to Employees and Contracts Terminated), whereas four indicators were reclassified from People and Performance to Value to Society in 2016 (i.e. Remuneration Packages to Employees, Taxes to Government, Dividends Paid and Contribution to Communities).

For the dropped indicators during the period, a number of indicators were written off from 2008-2017 in relation to Safety (eight indicators), People and Culture (one indicator) and Performance (five indicators). The reason behind this may be the insignificance of these indicators, from the perspective of BP's sustainability governance members, during the period of study.

During the period of examination, it has been articulated that the year-to-year change in the trends of the sustainability performance indicators reflects clearly the changes in BP sustainability governance and reporting that are shown in setting the mechanisms and structures for the sustainability dimensions. These dimensions and indicators were changed over time in terms of focus, volume and restructuration, both before and after the DWH incident, in such a manner as to manage BP's legitimacy (Mobus, 2005; Warsame et al., 2002) in the presence of the GoM and Geo Committees in 2010 and 2015, respectively. This indicates the increasing level of disclosure and transparency in sustainability governance and reporting and reflects, most importantly, the shift towards enhancing, to a greater extent, geopolitically responsible (Strategic) decision-making. 


\section{Conclusions and implications}

This paper has explored the emergence of sustainability governance and its role in enabling the BP response beyond the DWH incident. This examination has pulled out four insights that not only underline sustainability governance's characteristics, as presented in Table AI in the Appendix, but also advance existing understandings on such matters.

The first characteristic is broadness. This is interdisciplinary and concerns the interactions between corporate governance, social responsibility and business development. However, the concept goes beyond the environmental, social and safety dimensions, taking geopolitical matters into consideration, especially in multinational organisations. The geopolitics concerns the implications of politics for existing and future corporate investments worldwide. More specifically, the uncertainty and unpredictability of geopolitical implications have uncovered the limitations of executives and managers alike in formulating strategy and/or strategic (e.g. capital investment) decision-making (Elmassri et al., 2015; Huikku et al., 2018). This is a gap into which specific actors with a background in politics are invited (Maaloul et al., 2018; Wahab et al., 2017). As part of sustainability governance, measuring geopolitics objectively is still in its infancy stage, and further research attention is urged in this regard.

Dynamic is the second insight drawn in relation to sustainability governance (Essid and Berland, 2018). Sustainability governance is not operating in a vacuum. Rather, it interconnects the corporation and the societies in which BP were operating and where they were socially responsible. However, both sustainability governance and society's expectations interact dynamically to involve legitimisation, as a process (Dowling and Pfeffer, 1975). As society's expectations are evolving, corporations necessarily respond. By drawing on BP's experience, we argue that sustainability governance is a dynamic framework that focuses on significant sustainability issues for particular oversight, by means of which organisational response is shaped. This response to significations is not necessarily offered through its signalling tone, to either sustainability and/or annual reporting. Rather, it may extend to managerial changes within an organisation, such as strategizing and reporting on processes. Because of political instability, business strategy is kept dynamic by geopolitical threats, and this process underlines the strategizing process through which politicians are participating in, and influencing, strategic capital investment decisions. Such implications are, in turn, cascading down to the restructuring of sustainability reporting (metrics and indicators) in alignment with the identified significations for particular oversight. The outcomes of these processes then shape the preconditions needed for the manners in which sustainability performance should be reported.

The third characteristic of sustainability governance is agility. BP's organisational response to signs for particular oversight vary between the roles of the defender and those of the prospector (Hsieh et al., 2018; Wijethilake et al., 2017; Wijethilake and Ekanayake, 2018). BP's defender response was shaped to address the implications of DWH, and the key focus of this role was to re-build the trust between BP and US society. This orientation, however, has revealed several managerial implications, such as the forming of the GoM Committee, through which BP's response to the legal, social and environmental and safety implications of the DWH incident were rigidly governed. Having five years of accumulated experience in dealing with the DWH incident enabled BP to extend its organisational focus and to give attention to prospective anxieties that are created by political instability in areas in which $\mathrm{BP}$ is investing or is intending to invest. This prospector position went beyond mitigating the existing concerns of the society and focused on looking forward, so as to identify and assess the intimations of geopolitics on investments. 
SAMPJ

11,1

Interdependence is the fourth characteristic of sustainability governance. This emphasises the tightness of the inter-controls at board level, which have been informed by the DWH incident. That is, no omission or overlapping in performing tasks across the board committees. By drawing on BP, we suggest that two principles underpin interdependence, namely, structural and directional interdependence. The structural interdependence concerns functionality, and it deals with key actors' memberships, relevant skills, experience and tasks. For instance, Chairs and members have memberships of more than one committee that is involved in sustainability governance, and they are equipped with the relevant skills and experience. More importantly, all of the committees pertaining to sustainability governance are assigned tasks that are interdependent with each other. Overall, the outcomes and values of sustainability governance-based control are interdependent. Directional interdependence underlines two forms of accountability, namely, the vertical and the horizontal. Whilst committees pertaining to sustainability governance are vertically accountable to BP's GCE, they are also horizontally accountable to each other, as they are interconnected through their key members, alongside the GCE.

The aforementioned characteristics also have practical implications for organisations, policy-makers, regulators and accounting education alike. First, sustainability governance could be constituted in the form of a department, team or committee. Whatever form it takes should be drawn on actors who are not only knowledgeable in corporate social responsibility but who are also visionary actors experienced in the geopolitical risks that may threaten an organisation's existence. Whilst vertical interdependence, represented in top management commitment, is important in enabling such a mechanism to work effectively, lateral interdependences, through cross-memberships, is critical. Policy-makers of corporate governance may need to rethink the existing codes and develop guidelines for specialised committees. Such guidelines could either be experimented with through further research projects within accounting programs, and/or by surveying regulators about the effectiveness of sustainability governance in minimising incidents within corporations.

Second, the sustainability governance agenda should be viewed as being dynamic, rather than static. This is because neither the business environment nor society's expectations is stable. In these circumstances, sustainability governance should be agile in managing legitimacy and protecting reputation. This urges organisations' attention to not be limited to a focus on social and environmental concerns but to also extend it to include the geopolitical threats within which investments operate. However, learned lessons from new incidents, concluded by regulators, should be shared with policy-makers, so as to revise the existing codes, and with educational institutions, for educational purposes.

Both sustainability governance's characteristics and implications raise puzzling questions for future research, which should explore, on a large scale and/or in more depth, the interactions of sustainability governance with (a) strategy, (b) the role of political connections and (c) corporate performance.

\section{Notes}

1. BP began life in 1909 and continued to flourish as an integrated oil and gas company, with the ambition today of providing energy through low carbon products, both on land and offshore.

2. See, the BP website: www.bp.com/en/global/corporate/what-we-do/bp-at-a-glance.html, and the Reuters website: www.reuters.com/finance/stocks/companyProfile/BP

3. See, the Sustainable Brands Report on 19 February 2015: www.sustainablebrands.com/ news_and_views/marketing_comms/leon_kaye/five_years_after_deepwater_horizon_can_bp_ repair_its_reputa 
4. See, the Daily Telegraph report on 20 April 2015: www.telegraph.co.uk/news/worldnews/ northamerica/usa/11546654/BP-oil-spill-Five-years-after-worst-environmental-disaster-in-US-historyhow-bad-was-it-really.html

5. BP Annual Reports for the period 2008-2017 are available at: www.bp.com/en/global/corporate/ investors/results-and-reporting/annual-report/annual-reporting-archive.html

6. BP Sustainability Reports for the period 2008-2017 are available at: www.bp.com/en/global/ corporate/sustainability/about-our-report/downloads-and-archive.html

Sustainability governance and legitimisation processes

7. According to the previous literature (e.g., s: Scapens, 1990; and Yin, 2009), the form of an archival-based case study illustrates an extensive inquiry via examining a single case within its particular context, in order to understand the present BP dynamics as a unit of analysis for the shaping of SG. As a research strategy, this case will comprise a logical plan for covering an appropriate structure, as well as data collection and analysis, by gathering detailed information about $\mathrm{BP}$ over a long period with a view to obtaining in-depth knowledge.

\section{References}

Abdalla, Y.A. and A.K, S.-N. (2015), "Pressures for sustainability practices in an oil and gas company: evidence from Sudan", Qualitative Research in Accounting and Management, Vol. 12 No. 3, pp. 256-286.

Aerts, W. (2005), "Picking up the pieces: impression management in the retrospective attributional framing of accounting outcomes", Accounting Organizations and Society, Vol. 30 No. 6, pp. 493-517.

Ahrens, T., Becker, A., Burns, J., Chapman, C.S., Granlund, M., Habersam, M., Hansen, A., et al. (2008), "The future of interpretive accounting research - a polyphonic debate", Critical Perspectives on Accounting, Vol. 19 No. 6, pp. 840-866.

Albertini, E. (2018), "The contribution of management control systems to environmental capabilities", Journal of Business Ethics, available at: https://doi.org/10.1007/s10551-018-3810-9.

Alkaraan, F. (2016), "Strategic investment decisionmaking - scanning and screening investment opportunities: the expansion of Guinness in West Africa", Meditari Accountancy Research, Vol. 24 No. 4, pp. 505-526.

Boyd, B.K., Haynes, K.T. and Zona, F. (2011), "Dimensions of CEO-board relations", Journal of Management Studies, Vol. 48 No. 8, pp. 1892-1923.

BP plc (2010), "Annual report and form-20F”, available at: www.bp.com/content/dam/bp/pdf/investors/ bp-annual-report-and-form-20f-2010.pdf (accessed 29 January 2018).

BP plc (2011), "Annual report and form-20F", available at: www.bp.com/content/dam/bp/pdf/investors/ bp-annual-report-and-form-20f-2011.pdf (accessed 29 January 2018).

BP plc (2015), “Annual report and form-20F”, available at: www.bp.com/content/dam/bp/pdf/investors/ bp-annual-report-and-form-20f-2015.pdf (accessed 29 January 2018).

BP plc (2016), "Annual report and form-20F”, available at: www.bp.com/content/dam/bp/en/corporate/ pdf/investors/bp-annual-report-and-form-20f-2016.pdf (accessed 29 January 2018).

BP plc (2017), "Annual report and form-20F”, available at: www.bp.com/content/dam/bp/en/corporate/ pdf/investors/bp-annual-report-and-form-20f-2017.pdf (accessed 29 January 2018).

Cho, C.H. and Patten, D.M. (2007), "The role of environmental disclosures as tools of legitimacy: a research note", Accounting, Organizations and Society, Vol. 32 Nos 7/8, pp. 639-647.

Deegan, C., Rankin, M. and Tobin, J. (2002), "An examination of the corporate social and environmental disclosures of BHP from 1983-1997: a test of legitimacy theory", Accounting, Auditing and Accountability Journal, Vol. 15 No. 3, pp. 312-343. 
SAMPJ

11,1

Diouf, D. and Boiral, O. (2017), "The quality of sustainability reports and impression management", Accounting, Auditing and Accountability Journal, Vol. 30 No. 3, pp. 643-667.

Dowling, J. and Pfeffer, J. (1975), "Organizational legitimacy: social values and organizational behavior", The Pacific Sociological Review, Vol. 18 No. 1, pp. 122-136.

El-Bassiouny, D. and Letmathe, P. (2018), "The adoption of CSR practices in Egypt: internal efficiency or external legitimation?", Sustainability Accounting, Management and Policy Journal, Vol. 26 doi: 10.1108/SAMPJ-10-2017-0126.

Elmassri, M.M., Harris, E.P. and Carter, D.B. (2015), “Accounting for strategic investment decisionmaking under extreme uncertainty", The British Accounting Review, Vol. 48 No. 2, pp. 151-168.

Essid, M. and Berland, N. (2018), "Adoption of environmental management tools: the dynamic capabilities contributions", Sustainability Accounting, Management and Policy Journal, Vol. 9 No. 3, doi: 10.1108/SAMPJ-09-2017-0099.

Grabner, I. and Moers, F. (2013), "Management control as a system or a package? Conceptual and empirical issues", Accounting, Organizations and Society, Vol. 38 Nos 6/7, pp. 407-419.

Gray, R., Kouhy, R. and Lavers, S. (1995), "Corporate social and environmental reporting: a review of the literature and a longitudinal study of UK disclosure", Accounting, Auditing and Accountability Joumal, Vol. 8 No. 2, pp. 47-77.

Guthrie, J. and Parker, L.D. (1989), "Corporate social reporting:a rebuttal of legitimacy theory", Accounting and Business Research, Vol. 19 No. 76, pp. 343.

Haniffa, R.M. and Cooke, T.E. (2005), "The impact of culture and governance on corporate social reporting", Journal of Accounting and Public Policy, Vol. 24 No. 5, pp. 391-430.

Heggen, C. (2018), "The role of value systems in translating environmental planning into performance", The British Accounting Review, Vol. 51, No. 2, pp. 130-147.

Ho, S.S.M. and Shun Wong, K. (2001), "A study of the relationship between corporate governance structures and the extent of voluntary disclosure", Journal of International Accounting, Auditing and Taxation, Vol. 10 No. 2, pp. 139-156.

Hsieh, C.-C., Ma, Z. and Novoselov, K.E. (2018), "Accounting conservatism, business strategy, and ambiguity", accounting”, Organizations and Society, Vol. 30, pp. 1-15.

Huikku, J., Karjalainen, J. and Seppälä, T. (2018), "The dynamism of pre-decision controls in the appraisal of strategic investments", The British Accounting Review, Vol. 50 No. 5, pp. 516-538.

Hutchison, A.J., Johnston, L.H. and Breckon, J.D. (2010), "Using QSR-NVivo to facilitate the development of a grounded theory project: an account of a worked example", International Journal of Social Research Methodology, Vol. 13 No. 4, pp. 283-302.

Jollands, S., Akroyd, C. and Sawabe, N. (2015), "Core values as a management control in the construction of "sustainable development", Qualitative Research in Accounting and Management, Vol. 12 No. 2, pp. 127-152.

Kaur, A. and Lodhia, S. (2018), "Stakeholder engagement in sustainability accounting and reporting", Accounting, Auditing and Accountability Journal, Vol. 31 No. 1, pp. 338-368.

Kikooma, J.F. (2004) "Using qualitative data analysis software in a social constructionist study of entrepreneurship", Qualitative Research Journal, Vol. 10 No. 1, pp. 40-51.

Lindblom, C.K. (1993), "The implications of organisational legitimacy for corporate social performance and disclosure", The Critical Perspectives on Accounting Conference, New York, NY.

Lueg, R. and Radlach, R. (2016), "Managing sustainable development with management control systems: a literature review", European Management Journal, Vol. 34 No. 2, pp. 158-171.

Maaloul, A., Chakroun, R. and Yahyaoui, S. (2018), "The effect of political connections on companies' performance and value", Journal of Accounting in Emerging Economies, Vol. 8 No. 2, pp. 185-204. 
Maclagan, P. (1999), “Corporate social responsibility as a participative process”, Business Ethics: A European Review, Vol. 8 No. 1, pp. 43-49.

Majumder, M.T.H., Akter, A. and Li, X. (2017), "Corporate governance and corporate social disclosures: a meta-analytical review", International Journal of Accounting and Information Management, Vol. 25 No. 4, pp. 434-458.

Michelon, G. and Parbonetti, A. (2012), "The effect of corporate governance on sustainability disclosure", Journal of Management and Governance, Vol. 16 No. 3, pp. 477-509.

Milne, M.J. and Patten, D.M. (2002), "Securing organizational legitimacy: an experimental decision case examining the impact of environmental disclosures", accounting", Accounting, Auditing and Accountability Journal, Vol. 15 No. 3, pp. 372-405.

Mobus, J.L. (2005), "Mandatory environmental disclosures in a legitimacy theory context", Accounting, Auditing and Accountability Journal, Vol. 18 No. 4, pp. 492-517.

Narayanan, V. and Adams, C.A. (2016), "Transformative change towards sustainability: the interaction between organisational discourses and organisational practices", Accounting and Business Research, Vol. 47 No. 3, pp. 344-368.

Noronha, C., Leung, T.C.H. and Lei, O.I. (2015), "Corporate social responsibility disclosure in chinese railway companies: corporate response after a major train accident”, Sustainability Accounting, Management and Policy Journal, Vol. 6 No. 4, pp. 446-474.

O'Donovan, G. (2002), "Environmental disclosures in the annual report: Extending the applicability and predictive power of legitimacy theory", Accounting, Auditing and Accountability Journal, Vol. 15 No. 3, pp. 344-371.

Parker, L.D. (2005), "Social and environmental accountability research: a view from the commentary box", Accounting, Auditing and Accountability Journal, Vol. 18 No. 6, pp. 842-860.

Parker, L.D. (2012), "Qualitative management accounting research: assessing deliverables and relevance", Critical Perspectives on Accounting, Vol. 23 No. 1, pp. 54-70.

Passetti, E., Cinquini, L., Marelli, A. and Tenucci, A. (2014), "Sustainability accounting in action: Lights and shadows in the Italian context", The British Accounting Review, Vol. 46 No. 3, pp. 295-308.

Patten, D.M. (1992), "The address the social issues inherently related to the organizations. Unlike economic performance which could be quantitatively measured via profits, social performance was outside the realm of the market system. Accordingly, social concerns were add", Accounting, Organizations and Society, Vol. 17 No. 5, pp. 471-475.

Rezaee, Z. (2016), "Business sustainability research: a theoretical and integrated perspective", Journal of Accounting Literature, Vol. 36, pp. 48-64.

Riccaboni, A. and Leone, E.L. (2010), "Implementing strategies through management control systems: the case of sustainability", International Journal of Productivity and Performance Management, Vol. 59 No. 2, pp. 130-144. Taticchi, P. (Ed.).

Scapens, R. (1990), "Researching management accounting practice: the role of case study methods", British Accounting Review, Vol. 22, pp. 259-281.

Scapens, R. (2004), "Doing case study research", in Humphrey, C. and Lee, B. (Eds), The Real Life Guide to Accounting Research: A behind-the-Scenes View of Using Qualitative Research Methods, Elsevier Ltd, Oxford, pp. 257-279.

Shaukat, A., Qiu, Y. and Trojanowski, G. (2016), "Board attributes, corporate social responsibility strategy, and corporate environmental and social performance", Journal of Business Ethics, Vol. 135 No. 3, pp. 569-585.

Stein, V. and Wiedemann, A. (2016), "Risk governance: conceptualization, tasks, and research agenda", Journal of Business Economics, Vol. 86 No. 8, pp. 813-836.

Suchman, M.C. (1995), "Managing legitimacy: Strategic and institutional approaches", The Academy of Management Review, Vol. 20 No. 3, pp. 571-610. 
Van der Meer-Kooistra, J. and Scapens, R. (2008), "The governance of lateral relations between and within organisations", Management Accounting Research, Vol. 19 No. 4, pp. 365-384.

Vourvachis, P. and Woodward, T. (2015), "Content analysis in social and environmental reporting research: trends and challenges", Journal of Applied Accounting Research, Vol. 16 No. 2, pp. 166-195.

Vourvachis, P., Woodward, T., Woodward, D.G. and Patten, D.M. (2016), "CSR disclosure in response to major airline accidents: a legitimacy-based exploration", Sustainability Accounting, Management and Policy Journal, Vol. 7 No. 1, pp. 26-43.

Wahab, E.A.A., Ariff, A.M., Marzuki, M.M. and Sanusi, Z.M. (2017), "Political connections, corporate governance, and tax aggressiveness in Malaysia”, Asian Review of Accounting, Vol. 25 No. 3, pp. 424-451.

Warsame, H., Simmons, C.V. and Neu, D. (2002), "Responding to 'discrediting' events: annual report disclosure responses to environmental fines", Accounting and the Public Interest, Vol. 2 No. 1, pp. 22-40.

Wijethilake, C. and Ekanayake, A. (2018), "Proactive strategic responses to corporate sustainability pressures: a sustainability control system framework", Advances in Management Accounting, pp. 129-173.

Wijethilake, C., Munir, R. and Appuhami, R. (2017), "Strategic responses to institutional pressures for sustainability", Accounting, Auditing and Accountability Journal, Vol. 30 No. 8, pp. 1677-1710.

Yin, R. (2009), Case Study Research: Design and Methods (Applied Social Research Methods), SAGE, Vol. 5.

Yuan, Y., Lu, L.Y., Tian, G. and Yu, Y. (2018), "Business strategy and corporate social responsibility”, Journal of Business Ethics, available at: https://doi.org/10.1007/s10551-018-3952-9

Zhao, N. and Patten, D.M. (2016), "An exploratory analysis of managerial perceptions of social and environmental reporting in China: Evidence from state-owned enterprises in Beijing", Sustainability Accounting, Management and Policy Journal, Vol. 7 No. 1, pp. 80-98.

\section{Further reading}

BP plc (2008), "Annual report and accounts”, available at: www.bp.com/content/dam/bp/pdf/investors/ bp-annual-report-accounts-2008.pdf (accessed 29 January 2018).

BP plc (2009), "Annual report and accounts”, available at: www.bp.com/content/dam/bp/pdf/investors/ bp-annual-report-accounts-2009.pdf (accessed 29 January 2018).

BP plc (2012), "Annual report and form-20F”, available at: www.bp.com/content/dam/bp/pdf/investors/ bp-annual-report-and-form-20f-2012.pdf (accessed 29 January 2018).

BP plc (2013), "Annual report and form-20F”, available at: www.bp.com/content/dam/bp/pdf/investors/ bp-annual-report-and-form-20f-2013.pdf (accessed 29 January 2018).

BP plc (2014), “Annual report and form-20F”, available at: www.bp.com/content/dam/bp/pdf/investors/ bp-annual-report-and-form-20f-2014.pdf (accessed 29 January 2018). 
SAMPJ

11,1

276

Figure A2.

Structural analysis of British Petroleum sustainability dimensionsindicators report (Summary)

\begin{tabular}{|c|c|c|c|c|c|c|c|c|c|c|c|c|}
\hline Dimensions & Codes & 2008 & 2009 & 2010 & 2011 & 2012 & 2013 & 2014 & 2015 & 2016 & 2017 & No. of Indicators in Average \\
\hline Safety & $\mathbf{S}$ & 25 & 11 & 10 & 11 & 13 & 13 & 13 & 13 & 14 & 16 & 13.9 \\
\hline Greenhouse Gas Emissions & G & & & & & & & & & 11 & 17 & 14 \\
\hline Value to Society & V & & & & & & & & & 4 & 4 & 4 \\
\hline Environment & $\mathbf{E}$ & & 8 & 11 & 10 & 9 & 10 & 10 & 10 & 9 & 11 & 9.78 \\
\hline People and Culture & PC & 7 & 9 & 11 & 11 & 11 & 10 & 10 & 10 & 9 & 10 & 9.8 \\
\hline Performance & $\mathbf{P}$ & 9 & 8 & 8 & 8 & 8 & 8 & 8 & 8 & & & 8.125 \\
\hline
\end{tabular}




\begin{tabular}{|c|c|c|c|c|c|c|c|c|c|c|}
\hline Indicators & జ్ఞ & 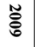 & $\stackrel{\cong}{\Xi}$ & $\stackrel{\check{\Xi}}{\varrho}$ & 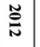 & $\stackrel{\widetilde{\Xi}}{\omega}$ & 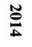 & 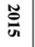 & 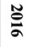 & $\stackrel{ }{\leftrightarrows}$ \\
\hline Fatalities-employees & $\mathrm{S}$ & $\mathrm{S}$ & $\mathrm{S}$ & $\mathrm{S}$ & $\mathrm{S}$ & $\mathrm{S}$ & $\mathrm{s}$ & $\mathrm{S}$ & $\mathrm{S}$ & S \\
\hline Fatalities - contractors & $\mathrm{s}$ & $\mathrm{s}$ & $\mathrm{s}$ & $\mathrm{S}$ & $\mathrm{s}$ & $\mathrm{S}$ & $\mathrm{s}$ & $\mathrm{s}$ & $\mathrm{S}$ & $\mathrm{S}$ \\
\hline Days away from work cases - workforce & $\mathrm{S}$ & $\mathrm{S}$ & $\mathrm{S}$ & $\mathrm{S}$ & $\mathrm{S}$ & $\mathrm{S}$ & $\mathrm{S}$ & $\mathrm{S}$ & $\mathrm{S}$ & $S$ \\
\hline Days away from work case frequency b (DAFWCF) - workforce & $\mathrm{S}$ & $\mathrm{S}$ & $\mathrm{S}$ & S & $\mathrm{S}$ & $\mathrm{S}$ & $\mathrm{s}$ & $\mathrm{S}$ & $\mathrm{S}$ & $S$ \\
\hline Recordable injuries - workforce & $\mathrm{S}$ & $\mathrm{S}$ & $\mathrm{s}$ & $\mathrm{S}$ & $\mathrm{s}$ & $\mathrm{S}$ & $\mathrm{s}$ & $\mathrm{S}$ & $\mathrm{S}$ & $\mathrm{S}$ \\
\hline Recordable injury frequency b (RIF) - workforce & $\mathrm{s}$ & $\mathrm{S}$ & $\mathrm{S}$ & $\mathrm{S}$ & $\mathrm{S}$ & $\mathrm{S}$ & $\mathrm{s}$ & $\mathrm{S}$ & $S$ & $S$ \\
\hline Hours worked - employees (million hours) & $\mathrm{S}$ & $\mathrm{S}$ & $\mathrm{S}$ & $\mathrm{S}$ & $\mathrm{S}$ & $\mathrm{S}$ & $\mathrm{S}$ & $\mathrm{S}$ & & \\
\hline Hours worked - contractors (million hours) & $\mathrm{S}$ & $\mathrm{S}$ & $\mathrm{S}$ & $\mathrm{S}$ & $\mathrm{S}$ & $\mathrm{S}$ & $\mathrm{S}$ & $\mathrm{S}$ & & \\
\hline Losses of primary containment c (number) & & & $\mathrm{S}$ & S & $\mathrm{S}$ & $\mathrm{S}$ & $\mathrm{s}$ & $\mathrm{S}$ & $\mathrm{S}$ & $S$ \\
\hline Tier 1 process safety events $\mathrm{d}$ (number) & & & & & $\mathrm{S}$ & $\mathrm{S}$ & $\mathrm{s}$ & $\mathrm{s}$ & $\mathrm{S}$ & $S$ \\
\hline Tier 2 process safety events $\mathrm{d}$ (number) & & & & & & $\mathrm{S}$ & $\mathrm{s}$ & $\mathrm{S}$ & $\mathrm{S}$ & $\mathrm{S}$ \\
\hline Number of Oil spills (>_one barrel) & $\mathrm{S}$ & $\mathrm{S}$ & $\mathrm{S}$ & $\mathrm{s}$ & $\mathrm{s}$ & $S$ & $\mathrm{~s}$ & $\mathrm{~S}$ & $S$ & $S$ \\
\hline Oil spills contained & & & & & & & & & S & $S$ \\
\hline Oil spills - to land and water (number) & & & $\mathrm{E}$ & E & $\mathrm{E}$ & $\mathrm{E}$ & $\mathrm{E}$ & $\mathrm{E}$ & $\mathrm{S}$ & $S$ \\
\hline Volume of oil spilled (million litres) & $\mathrm{S}$ & $\mathrm{S}$ & $\mathrm{E}$ & $\mathrm{E}$ & $\mathrm{S}$ & $\mathrm{S}$ & $\mathrm{s}$ & $\mathrm{S}$ & $\mathrm{S}$ & $S$ \\
\hline Volume of oil unrecovered (million litres) & $\mathrm{S}$ & $\mathrm{S}$ & $\mathrm{E}$ & $\mathrm{E}$ & $\mathrm{E}$ & $\mathrm{E}$ & $\mathrm{E}$ & $\mathrm{E}$ & $\mathrm{S}$ & S \\
\hline Severe vehicle accident rate (per million kilometres driven) & & & & & & & & & & S \\
\hline Total vehicle accident rate (per million kilometres driven) & & & & & & & & & & S \\
\hline Environmental and Safety fines ( $\$$ million) & $\mathrm{S}$ & E & $\mathrm{E}$ & $\mathrm{S}$ & $\mathrm{S}$ & $\mathrm{E}$ & $\mathrm{E}$ & E & $\mathrm{E}$ & E \\
\hline Sulphur dioxide (Kte) & $\mathrm{S}$ & & & & & & & & & \\
\hline Nitrogen oxides (Kte) & $\mathrm{s}$ & & & & & & & & & \\
\hline Non-methane hydrocarbons (Kte) & S & & & & & & & & & \\
\hline Discharges to water (Kte) & $\mathrm{s}$ & & & & & & & & & \\
\hline Fresh water withdrawal (million cubic metres) & $\mathrm{s}$ & & & & & & & & & \\
\hline Hazardous waste $\mathrm{j}$ (Kte) & $\mathrm{s}$ & & & & & & & & & \\
\hline Direct carbon dioxide (CO2)f (million tonnes (Mte)) & & & & & & & & & & $\mathrm{GO}$ \\
\hline Direct methane (Mte) & & & & & & & & & & GO \\
\hline Direct greenhouse gas (GHG)f (Mte $\mathrm{CO} 2$ equivalent (CO2e)) & & & & & & & & & & GO \\
\hline Indirect carbon dioxide $(\mathrm{CO} 2) \mathrm{h}(\mathrm{Mte})$ & & & & & & & & & & GO \\
\hline Real sustainable reductions in GHG emissions (Mte) & & & & & & & & & & $\mathrm{GO}$ \\
\hline Methane intensity (\%) & & & & & & & & & & GO \\
\hline Greenhouse gas intensity - Upstream (per thousand barrels of oil equivalent) & & & & & & & & & G & GE \\
\hline Greenhouse gas intensity - Refining (per utilized equivalent distillation capacity) & & & & & & & & & G & GE \\
\hline Greenhouse gas intensity - Petrochemicals (per thousand tonnes) & & & & & & & & & G & GE \\
\hline Carbon dioxide avoided through our renewables business (MteCO2e) & & & & & & & & & G & GE \\
\hline Direct carbon dioxide (CO2)f (million tonnes (Mte)) & $\mathrm{S}$ & $\mathrm{E}$ & $\mathrm{E}$ & E & $\mathrm{E}$ & $\mathrm{E}$ & $\mathrm{E}$ & $\mathrm{E}$ & G & GE \\
\hline Direct methane (Mte) & $\mathrm{S}$ & $\mathrm{E}$ & $\mathrm{E}$ & E & E & $\mathrm{E}$ & E & E & G & GE \\
\hline Direct greenhouse gas (GHG)f (Mte $\mathrm{CO} 2$ equivalent ( $\mathrm{CO} 2 \mathrm{e})$ ) & $\mathrm{S}$ & $\mathrm{E}$ & $\mathrm{E}$ & E & $\mathrm{E}$ & $\mathrm{E}$ & $E$ & $\mathrm{E}$ & G & GE \\
\hline Indirect carbon dioxide $(\mathrm{CO} 2) \mathrm{h}(\mathrm{Mte})$ & $\mathrm{S}$ & $\mathrm{E}$ & $\mathrm{E}$ & E & $\mathrm{E}$ & $\mathrm{E}$ & E & E & G & GE \\
\hline Real sustainable reductions in GHG emissions (Mtc) & & & & & & & & & G & GE \\
\hline Customer emissions (MteCO2) & $\mathrm{S}$ & $\mathrm{E}$ & $\mathrm{E}$ & E & $\mathrm{E}$ & $\mathrm{E}$ & $\mathrm{E}$ & $\mathrm{E}$ & G & GE \\
\hline Flaring (Upstream) (thousand tonnes (kte) of hydrocarbons) & $\mathrm{s}$ & $\mathrm{E}$ & $\mathrm{E}$ & $\mathrm{E}$ & $\mathrm{E}$ & $\mathrm{E}$ & E & $\mathrm{E}$ & G & $\mathrm{GO}$ \\
\hline Environmental expenditure (\$ million) & $\mathrm{S}$ & $\mathrm{E}$ & $\mathrm{E}$ & $\mathrm{E}$ & E & E & $\mathrm{E}$ & $\mathrm{E}$ & $\mathrm{E}$ & $\mathrm{E}$ \\
\hline Freshwater consumption (million m3) & & & & & & & & & $\mathrm{E}$ & E \\
\hline Percentage of withdrawal & & & & & & & & & E & $\mathrm{E}$ \\
\hline Water consumption intensity - group (tonnes water/tonnes production) $\mathrm{r}$ & & & & & & & & & E & $\mathrm{E}$ \\
\hline Freshwater withdrawal & & & & & & & & & $\mathrm{E}$ & $\mathrm{E}$ \\
\hline Discharges to water - Upstream & & & & & & & & & & E \\
\hline Discharges to water - Refining and chemicals & & & & & & & & & & E \\
\hline Air emissions - nitrogen oxides (thousand tonnes) & & & & & & & & & E & $\mathrm{E}$ \\
\hline Air emissions - sulphur oxides (thousand tonnes) & & & & & & & & & $\mathrm{E}$ & $\mathrm{E}$ \\
\hline Air emissions - non-methane hydrocarbons (thousand tonnes) & & & & & & & & & $\mathrm{E}$ & $\mathrm{E}$ \\
\hline Number of employees - group & PC & PC & PC & PC & PC & PC & PC & PC & PC & PC \\
\hline Number of employees - group leadership & PC & PC & PC & PC & PC & PC & PC & $\mathrm{PC}$ & PC & PC \\
\hline Women in-group leadership (\%) & $\mathrm{PC}$ & $\mathrm{PC}$ & $\mathrm{PC}$ & $\mathrm{PC}$ & PC & PC & $\mathrm{PC}$ & $\mathrm{PC}$ & PC & PC \\
\hline Women at management level (\%) & & & PC & $\mathrm{PC}$ & PC & PC & PC & PC & PC & PC \\
\hline People from UK and US racial minorities in-group leadership (\%) & $\mathrm{PC}$ & $\mathrm{PC}$ & PC & $\mathrm{PC}$ & PC & PC & PC & $\mathrm{PC}$ & $\mathrm{PC}$ & $\mathrm{PC}$ \\
\hline People from beyond the UK and US in group leadership (\%) & PC & PC & PC & $\mathrm{PC}$ & PC & PC & PC & $\mathrm{PC}$ & PC & $\mathrm{PC}$ \\
\hline Employee turnover $\mathrm{n}(\%)$ & & & PC & PC & PC & PC & PC & PC & PC & $\mathrm{PC}$ \\
\hline OpenTalk cases & $\mathrm{PC}$ & $\mathrm{PC}$ & PC & $\mathrm{PC}$ & PC & PC & $\mathrm{PC}$ & $\mathrm{PC}$ & $\mathrm{PC}$ & $\mathrm{PC}$ \\
\hline Dismissals for non-compliance and unethical behaviour & $\mathrm{PC}$ & $\mathrm{PC}$ & PC & PC & $\mathrm{PC}$ & PC & $\mathrm{PC}$ & PC & $\mathrm{PC}$ & $\mathrm{PC}$ \\
\hline Benefits to employees - including wages, salaries, share-based payments, benefits and pensions ( $\$$ million) & $\mathrm{P}$ & $\mathrm{PC}$ & PC & PC & PC & PC & PC & PC & V & V \\
\hline Contracts terminated or not renewed due to non-compliance or unethical behaviour & $\mathrm{P}$ & $\mathrm{PC}$ & PC & PC & PC & & & & & \\
\hline Employee engagement (\%) & & & & & & & & & & PC \\
\hline Total hydrocarbons produced (thousand barrels of oil equivalent (mboe) per day) & $\mathrm{P}$ & $\mathbf{P}$ & $\mathrm{P}$ & $\mathrm{P}$ & $\mathbf{P}$ & $\mathrm{P}$ & $\mathrm{P}$ & $\mathbf{P}$ & & \\
\hline Reserves replacement ratio (\%) & & $\mathbf{P}$ & $\mathrm{P}$ & $P$ & $\mathbf{P}$ & $\mathrm{P}$ & $P$ & $\mathbf{P}$ & & \\
\hline Total refinery throughputs (thousand barrels per day $(\mathrm{mb} / \mathrm{d})$ ) & $\mathrm{P}$ & P & $\mathrm{P}$ & $\mathrm{P}$ & $\mathrm{P}$ & $\mathrm{P}$ & $\mathrm{P}$ & $\mathbf{P}$ & & \\
\hline Total petrochemicals production (thousand tonnes (kte)) & $\mathrm{P}$ & $\mathbf{P}$ & $\mathrm{P}$ & $\mathrm{P}$ & $\mathbf{P}$ & $\mathrm{P}$ & $\mathrm{P}$ & $\mathbf{P}$ & & \\
\hline Replacement cost profit (loss)r ( $\$$ million) & $\mathrm{P}$ & $\mathbf{P}$ & $\mathrm{P}$ & $\mathrm{P}$ & $\mathbf{P}$ & $\mathrm{P}$ & $\mathrm{P}$ & $\mathbf{P}$ & & \\
\hline Taxes to governments - comprising income taxes and production taxes paid ( $\$$ million) & $\mathrm{P}$ & $\mathrm{P}$ & $P$ & $\mathrm{P}$ & $\mathrm{P}$ & $\mathrm{P}$ & $\mathrm{P}$ & $\mathrm{P}$ & V & V \\
\hline Dividends paid per shareholder (Billions \$) & $\mathrm{P}$ & $\mathrm{P}$ & $\mathrm{P}$ & $\mathrm{P}$ & $\mathrm{P}$ & $\mathrm{P}$ & $\mathrm{P}$ & $\mathrm{P}$ & V & V \\
\hline Contribution to communities ( $\$$ million) & $\mathrm{P}$ & $\mathbf{P}$ & $P$ & $\mathrm{P}$ & P & $P$ & $\mathrm{P}$ & $P$ & V & V \\
\hline
\end{tabular}

\section{Sustainability governance and legitimisation processes}

Figure A3.

Structural analysis of British Petroleum sustainability dimensionsindicators report (Detailed) 
SAMPJ

11,1

Table AI.

Characteristics

Sustainability governance

Sustainability

governance

characteristics and

dimensions

Broadness
Dynamic
Agility
Interdependence

Legitimacy governance (Conformance)

Dimensions

\section{Corresponding author}

Nader Elsayed can be contacted at: naderelsayed@outlook.com

For instructions on how to order reprints of this article, please visit our website: www.emeraldgrouppublishing.com/licensing/reprints.htm

Or contact us for further details: permissions@emeraldinsight.com 